\title{
CLEC10A Gene
}

National Cancer Institute

\section{Source}

National Cancer Institute. CLEC10A Gene. NCI Thesaurus. Code C122764.

This gene is involved in regulating adaptive and innate immune responses. 